\title{
MIARODAJNA MACIERZ SZTYWNOŚCI W MODELOWANIU PODATNOŚCI OGARNIĘTEGO POŻAREM STALOWEGO DOCZOLOWEGO WEZZLA RYGIEL - SŁUP
}

\begin{abstract}
Zaprezentowano i przedyskutowano procedure specyfikacji wyrazów macierzy sztywności elementu węzłowego, wykorzystywanej w szacowaniu podatności ogarniętego pożarem stalowego doczołowego węzła rygiel - słup. Postać tej macierzy determinowana jest przyjętym do szczegółowej analizy zastępczym modelem mechanicznym, stanowiącym układ odpowiednio połączonych sprężyn myślowo wprowadzonych do konstrukcji i odzwierciedlających reakcję wyodrębnionych składników węzła na przyłożone do nich wymuszenia o wartości jednostkowej.
\end{abstract}

Słowa kluczowe: macierz sztywności, węzeł podatny, element węzłowy, metoda składnikowa, pożar.

\section{Wprowadzenie}

Oszacowanie odporności ogniowej stalowego ramowego ustroju nośnego będzie wiarygodne jeśli w przeprowadzanej analizie uwzględni się narastająca ze wzrostem temperatury pożarowej podatność węzłów. Oznacza to, że węzły te będą w pożarze węzłami podatnymi nawet wtedy, gdy zostały zaprojektowane jako nominalnie sztywne przy założeniu wymogów podstawowej sytuacji projektowej. Różnice ilościowe skutkujące nazbyt optymistycznym oszacowaniem nośności i sztywności ramy eksponowanej na działanie ognia przy pominięciu tego typu wpływu mogą być znaczące, co pokazali autorzy niniejszego artykułu w pracy [1]. Na ogół przyjmuje się, że obiektywną miarą podatności węzła w pożarze jest zbiór charakterystyk $M-\phi$, wyrażających relacje pomiędzy przyłożonym do węzła momentem zginającym i generowanym przez

${ }^{1}$ Autor do korespondencji: Mariusz Maślak, Politechnika Krakowska, ul. Warszawska 24, 31-155 Kraków, tel.: +48126415673, e-mail: mmaslak@pk.edu.pl

2 Małgorzata Snela, Politechnika Lubelska, ul. Nadbystrzycka 38D, 20-618 Lublin, tel.: +48815384388, e-mail: m.snela@.pollub.pl 
to oddziaływanie obrotem. Jeśli założyć, że w danej chwili pożaru rozkład temperatury $\Theta$ w całym rozpatrywanym wę́le jest równomierny, to każdej wybranej wartości tej temperatury można przypisać reprezentatywną dla niej tego typu charakterystykę [2]. Należy przy tym podkreślić, że wprawdzie przy stosunkowo wysokich ryglach bezpośrednio sąsiadujących z żelbetową płytą stropową o dużej pojemności cieplnej różnice w stopniu nagrzania ich dolnej i górnej półki mogą być zauważalne (co odnotowano w normie [3]), to jednak w ogólności, na skutek dobrego przewodnictwa cieplnego stali konstrukcyjnej, temperatura w przekroju belki bardzo szybko się wyrównuje. Poza tym, przypisanie do węzła temperatury sąsiadującego z nim elementu konstrukcyjnego (na ogół belki lub słupa, w zależności od tego która wartość będzie bardziej niekorzystna) jest rozwiązaniem bezpiecznym, w rzeczywistości bowiem węzły pozostają nieco chłodniejsze w stosunku do ich otoczenia, co nie tylko jest wynikiem nagromadzenia dodatkowych elementów stalowych (nakładek, przykładek itp.), ale również samej geometrii ramy (ograniczona penetracja ciepła w jej trudniej dostępnych zakamarkach).

Uwzględnienie możliwości kwantyfikacji podatności węzła w konwencjonalnej analizie statycznej ramy wymaga aby był on reprezentowany przez niezależny element węzłowy, o nieskończenie małym rozmiarze, spełniający równość:

$$
\mathbf{F}=\mathbf{K}_{\mathbf{c}} \mathbf{u}
$$

w której $\mathbf{F}$ jest wektorem sił wewnętrznych generowanych w węźle, $\mathbf{K}_{\mathbf{c}}$ macierzą sztywności elementu węzłowego, natomiast $\mathbf{u}$ - wektorem uogólnionych przemieszczeń. Odniesienie wspomnianej powyżej analizy do wyjątkowej sytuacji projektowej pożaru rozwiniętego sprowadza się do bezwzględnej konieczności, aby równanie (1) rozwiązywać iteracyjnie, co zresztą wynika z silnie nieliniowego zachowania węzła. W takim ujęciu, przy oznaczeniu końców elementu węzłowego odpowiednio przez $i$ oraz $j$, oraz specyfikacji prawoskrętnego układu współrzędnych $x, y, z$, w którym oś $x$ jest osią normalną do przekroju poprzecznego, równanie to należy zapisać w postaci:

$$
\Delta \mathbf{F}=\mathbf{K}_{c}^{*} \Delta \mathbf{u}
$$

gdzie odpowiednio:

$$
\Delta \mathbb{F}^{T}=\left[\begin{array}{llllllllllll}
\Delta N_{x, i} & \Delta V_{y, i} & \Delta V_{z, i} & \Delta M_{x, i} & \Delta M_{y, i} & \Delta M_{z, i} & \Delta N_{x, j} & \Delta V_{y, j} & \Delta V_{z, j} & \Delta M_{x, j} & \Delta M_{y, j} & \Delta M_{z, j}
\end{array}\right]
$$

oraz:

$$
\Delta \mathbf{u}^{T}=\left[\begin{array}{llllllllllll}
\Delta u_{i} & \Delta v_{i} & \Delta w_{i} & \Delta \phi_{x, i} & \Delta \phi_{y, i} & \Delta \phi_{z, i} & \Delta u_{j} & \Delta v_{j} & \Delta w_{j} & \Delta \phi_{x, j} & \Delta \phi_{y, j} & \Delta \phi_{z, j}
\end{array}\right]
$$


Szczegółowa identyfikacja elementów macierzy $\mathbf{K}_{c}^{*}$, takich aby odzwierciedlały one zachowanie się rozpatrywanego węzła w pożarze, jest celem niniejszej pracy. Analiza dotyczy najbardziej typowego przypadku, to znaczy odpowiedzi na oddziaływanie zewnętrzne stalowego doczołowego węzła rygiel - słup, pokazanego na rys. 1. Należy dodać, że spośród wielu możliwych podejść iteracyjnych pozwalających na efektywne rozwiązanie równania (2), autorzy niniejszego opracowania rekomendowali do stosowania to, które opiera się na określaniu w kolejnych krokach przyrostowych miarodajnej sztywności siecznej [4].

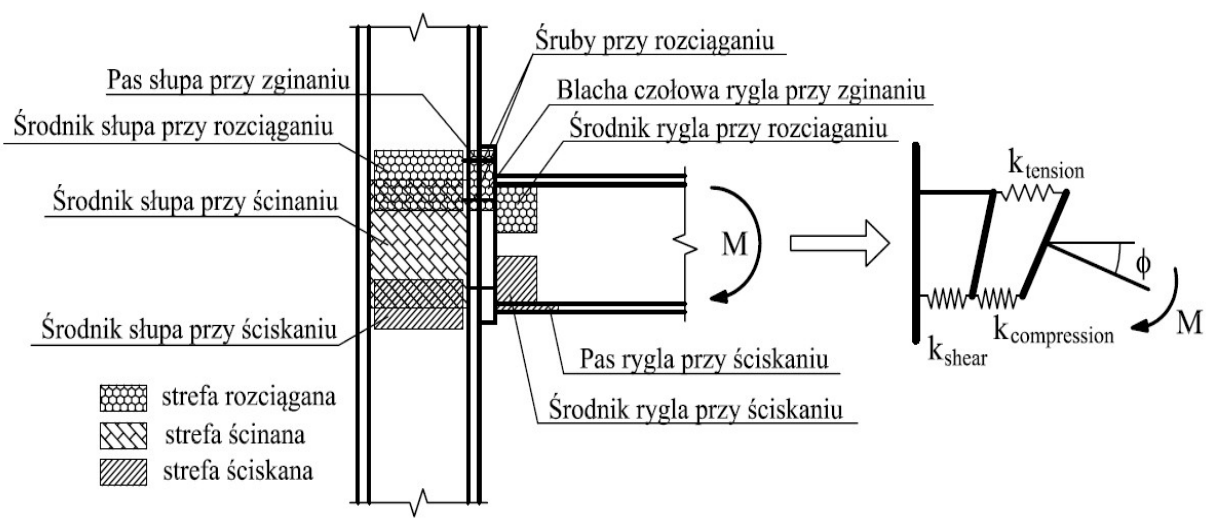

Rys. 1. Rozpatrywany w pracy stalowy, doczołowy węzeł rygiel - słup z wyodrębnionymi składnikami decydującymi o jego podatności. Z prawej typowy sposób modelowania jego pracy poprzez specyfikację zastępczego modelu mechanicznego.

Fig. 1. The steel end-plate beam-to-column joint, considered in the article, with the separated components determining its flexibility. On the right, a typical approach to modelling the joint behaviour through the specification of its equivalent mechanically-based model.

\section{Konwencjonalne modele mechaniczne wykorzystywane przy określaniu podatności stalowego doczołowego węzła rygiel - słup.}

Relacja moment - obrót $(M-\phi)$ miarodajna w sytuacji pożaru, przy zadanej temperaturze węzła, może zostać zbudowana w sposób uproszczony, poprzez odpowiednią modyfikację znanej a priori krzywej bazowej, skonstruowanej w odniesieniu do tego samego węzła przy założeniu podstawowej sytuacji projektowej [5]. W pracy [6] autorzy artykułu wykazali jednak, że nie w każdym przypadku będzie ona równoważna analogicznej relacji wyspecyfikowanej po analizie wszystkich potencjalnie możliwych mechanizmów zniszczenia elementów węzła poddanych działaniu temperatury pożarowej. Z oczywistych względów to drugie podejście trzeba uznać za bardziej wiarygodne. Opiera się 
ono na uogólnieniu na sytuację pożaru klasycznego algorytmu metody składnikowej. W tego typu analizie należy najpierw zidentyfikować podstawowe składniki (komponenty) węzła, determinujące jego zachowanie pod obciążeniem, następnie każdemu $\mathrm{z}$ takich elementów przypisać charakter wytężenia (rozciaganie, ściskanie, zginanie, ścinanie itp.), aby w końcu zamodelować oddziaływanie poszczególnych składników poprzez odpowiednie sprężyny, myślowo wprowadzone do węzła. Kluczowym jest tu połączenie wszystkich zidentyfikowanych wcześniej sprężyn we wspólny mechanizm, na ogół szeregowo równoległy, taki aby jego reakcja na oddziaływanie zewnętrzne była analogiczna do przewidywanego zachowania węzła. Ważne jest zatem nie tylko dopasowanie odpowiedniego stopnia skrępowania potencjalnych odkształceń podłużnych czy poprzecznych, ale również $\mathrm{w}$ miarę precyzyjne zamodelowanie faktycznej podatności na poszczególne obroty. Aby tego dokonać każdej z rozpatrywanych sprężyn musi być przypisany parametr $k_{i}$ charakteryzujący jej reakcję na przyłożone do niej wymuszenie jednostkowe. Szczegółowa identyfikacja tych parametrów, odniesiona do sytuacji pożaru, wymaga osobnego, bardzo obszernego opracowania. Opiera się ona bowiem w wielu przypadkach na rozbudowanych i wieloczynnikowych modelach strukturalnych, zależnych od geometrii składników węzła, w szczególności zaś od wzajemnej proporcji ich wymiarów. Trzeba przy tym podkreślić, że są to na ogół parametry o silnie nieliniowej zależności względem temperatury $\Theta$. W niniejszej analizie zakłada się że parametry te są już jakościowo i ilościowo określone i znane a priori. Pozostaje zatem ustalić miarodajny sposób połączenia poszczególnych sprężyn, taki aby złożyły się one na mechanizm o łatwej do zidentyfikowania strukturze formalnej, determinującej wartości elementów macierzy sztywności $\mathbf{K}_{c}^{*}$.

Niech szczegółowej analizie zostanie poddany węzeł pokazany na rys. 1. Na rysunku tym wyspecyfikowano poszczególne składniki węzła mające wpływ na jego wynikową nośność i sztywność oraz przypisano im sposób przenoszenia przyłożonych do nich obciążeń (rozciaganie, ściskanie, zginanie, ścinanie itp.). Pokazano również skojarzony z tym węzłem zastępczy model mechaniczny odwzorowujący jego zachowanie po przyłożeniu obciążenia [2]. Łatwo zauważyć, że zastosowano w tym przypadku szeregowo - równoległy sposób połączenia poszczególnych sprężyn, przy czym każda pojedyncza sprężyna została usytuowana horyzontalnie, na odpowiednim ramieniu względem osi rygla. Uogólniając, należy zauważyć, że tego typu modele budowane są zawsze w oparciu o równolegle zorientowane zastępcze sprężyny, a odpowiednia podatność obrotowa węzła uzyskiwana jest poprzez dobór poszczególnych parametrów $k_{i}$ oraz towarzyszących tym sprężynom ramion działania obciążenia (czyli $h_{i}$ ). Typowy schemat takiego modelu dotyczącego jednostronnego węzła belka słup pokazano na rys. 2 . 


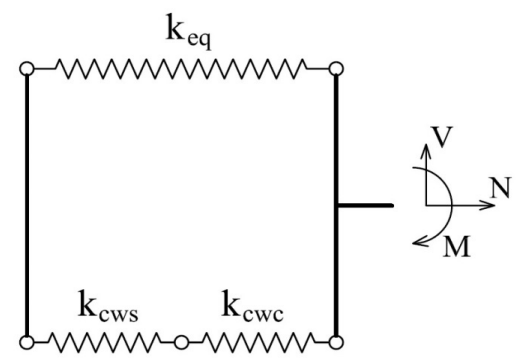

Rys. 2. Klasyczny szeregowo - równoległy układ sprężyn zorientowanych horyzontalnie, stosowany do kwantyfikacji podatności jednostronnego doczołowego węzła rygiel - słup.

Fig. 2. The classic serial - parallel system of horizontally oriented springs, used to quantify the flexibility of a single-sided end-plate beam-to-column joint.

Zauważmy, że górna sprężyna charakteryzowana jest w tym przypadku parametrem $k_{e q}$, który jest miarą podatności wynikającej ze współpracy rozciąganego środnika słupa (cwt - column web in tension), zginanej półki słupa ( $c f b$ - column flange in bending), zginanej blachy czołowej rygla (epb - end-plate in bending) oraz rozciaganych śrub (bt-bolts in tension). Sprężyna ta jest zatem ekwiwalentem szeregowego łańcucha łączącego sprężyny modelujące oddziaływanie wymienionych wcześniej składników węzła. $Z$ drugiej strony dolna sprężyna łączy w sobie oddziaływanie generowane przez ściskany środnik słupa (cwc - column web in compression) oraz przez ścinaną część tego samego środnika (cws - column web in shear). Pierwsze próby wprowadzenia zastępczego elementu węzłowego do modelowania podatności tego typu węzła, oparte na analogii równoległego układu sprężyn, zostały podjęte przez C. Poggi [7] a następnie przez W. Atamaza - Sibai i F. Freya [8]. W obu przypadkach do analizy zastosowano odcinkowo liniowe relacje modelujące sztywności poszczególnych sprężyn. Rozpatrywano przy tym niezależnie zależności moment - obrót i siła - przemieszczenie. Takie podejście nie dawało zatem możliwości uwzględnienia wpływu siły podłużnej (ściślej - interakcji $M-N$ ) ani też siły poprzecznej (interakcji $M-V$ ) na wynikową podatność obrotową węzła. Badanie tego typu interakcji stało się możliwe dopiero po odpowiednim udoskonaleniu proponowanych modeli teoretycznych, co jednak wiązało się z dość znaczną komplikacją procedury obliczeniowej [9]. Szersza weryfikacja tak skonstruowanych modeli, zarówno doświadczalna jak i numeryczna, znalazła odzwierciedlenie w szczegółowych rekomendacjach normy PN-EN 1993-1-8 [10], w których na podstawie wyników uzyskanych po analizie bardziej złożonych układów sprężyn definiuje się modele uproszczone, zalecane do stosowania w praktyce inżynierskiej. Modele te są szeroko komentowane również w literaturze krajowej (na przykład w pracy [11]). 


\section{Modele pozwalające na uwzględnienie interakcji M-N i/lub interakcji M-V.}

Jednym z pierwszych modeli pozwalających na uwzględnienie w sposób bezpośredni wpływu siły osiowej $N$ i/lub siły poprzecznej $V$ na reakcję zginanego stalowego doczołowego węzła podatnego rygiel - słup był model opracowany przez $T$. $Q . L i$ z zespołem [12]. Zaproponowano w nim użycie dwóch par sprężyn, z których pierwsza para została usytuowana pionowo, natomiast druga - poziomo (rys. 3). Obie pary doczepiono do nieskończenie sztywnych ramion. Tego rodzaju układ dawał możliwość jakościowej i ilościowej specyfikacji obydwu podstawowych stopni swobody, to znaczy zarówno stopnia czystotranslacyjnego, jak i rotacyjnego.

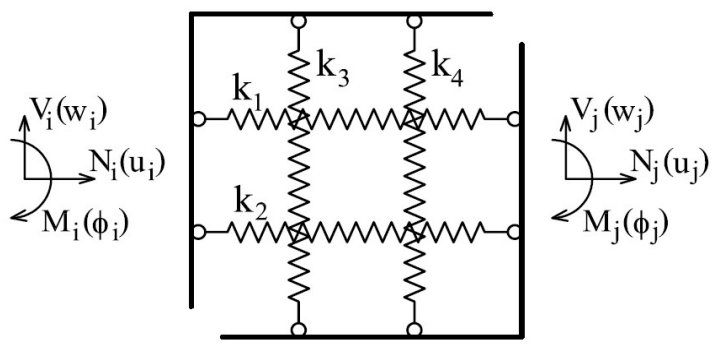

Rys. 3. Sprzężony układ sprężyn, pozwalający na uwzględnienie w sposób bezpośredni reakcji węzła na działanie siły poprzecznej.

Fig. 3. The coupled spring arrangement, which allows for direct consideration of the joint response to the impact of the transverse force.

Znaczącym udoskonaleniem tego rozwiązania był układ sprężyn zaproponowany przez E. Bayo z zespołem [13]. Reakcję środnika słupa na przyłożone obciążenie zamodelowano tu, podobnie jak w poprzednio opisywanym modelu, poprzez współdziałanie dwóch sprężyn, to znaczy odpowiednio jednej odpowiadającej za pracę jego części ściskanej $(c w c)$ i drugiej, modelującej zachowanie strefy ścinanej (cws). Nie zostały one jednak w tym przypadku połączone szeregowo. Co prawda pierwsza z nich została zorientowana horyzontalnie, pozostając sprężyną typowo translacyjną, za to drugą zorientowano diagonalnie w stosunku do wszystkich pozostałych sprężyn. Do tak skonstruowanego modelu pracy środnika słupa trzeba jeszcze dodać niezależne sprężyny translacyjne, charakteryzowane parametrami $k_{e q, 1}$ i $k_{e q, 2}$, odwzorowujące oddziaływanie rozciagganych składników węzła, odpowiednio po jego lewej i prawej stronie. Schemat zaproponowanego układu pokazano na rys. 4 odnosząc go tym razem do klasycznego węzła dwustronnego. Należy podkreślić, że w takim ujęciu węzeł podatny modelowany jest przy pomocy elementu czterowęzłowego, o dziewięciu stopniach swobody. Odróżnia go to zatem od rozpatrywanych do tej po- 
ry typowych elementów dwuwęzłowych. Poza tym element ten nie jest już nieskończenie mały. Jego rozmiar determinuje bowiem wysokość przekroju poprzecznego słupa oraz ramię działania sił poziomych przekazywanych z rygli.

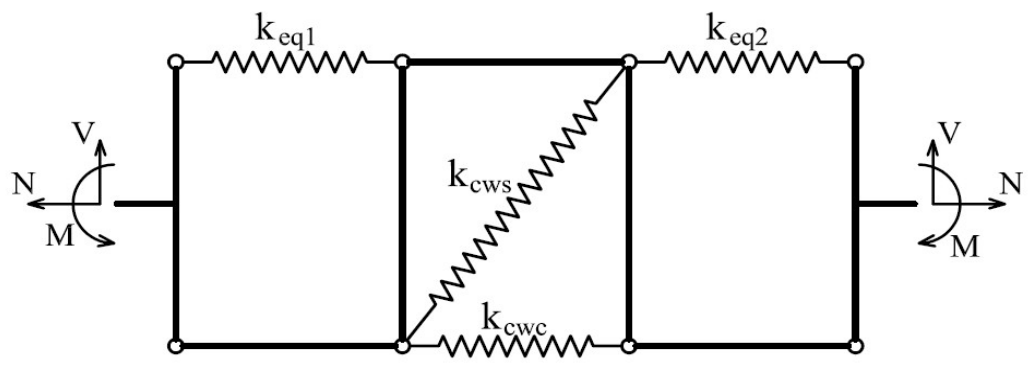

Rys. 4. Układ sprężyn modelujący pracę dwustronnego doczołowego węzła rygiel - słup, sprzężony $\mathrm{z}$ diagonalnie zorientowaną sprężyną odzwierciedlającą wpływ ścinania panelu środnika słupa - według [13],

Fig. 4. The system of the springs modelling the behaviour of a double-sided beam-to-column joint, coupled with a diagonally oriented spring reflecting the impact of the shear force on the column web - according to [13].

Oczywiście prezentowany model można rozbudować przez dodanie kolejnej sprężyny modelującej ścinanie środnika słupa. Będzie ona wtedy umieszczona na drugiej przekątnej rozpatrywanego elementu węzłowego. Uogólniając, należy stwierdzić, że zastosowanie zastępczego diagonalnego elementu prętowego należy do podstawowych technik modelowania zachowania się ścinanych paneli blachownic stalowych, zwłaszcza tych charakteryzujących się znaczną smukłością płytową. Podstawową zaletą opisanego powyżej modelu jest możliwość przeprowadzenia sprzężonej analizy statycznej, uwzględniającej równoczesne zginanie, ściskanie (lub rozciąganie) i ścinanie elementów węzła. Cechy tej nie da się przypisać do modelu proponowanego przez F. Blocka z zespołem $[14,15]$. W tym ujęciu do opisu odpowiedzi węzła na przyłożoną do niego siłę poprzeczną wykorzystuje się usytuowaną pionowo sprężynę o charakterystyce $k_{S}$. Wszystkie pozostałe sprężyny zostają zorientowane poziomo. Strefa rozciągana węzła modelowana jest przez dwa połączone szeregowo króćce teowe. Pierwszy, odzwierciedlany przez rozciagane sprężyny o charakterystyce $k_{t c}$, symuluje działanie śrub i zginanego pasa słupa, drugi natomiast, zapisany poprzez rozciągane sprężyny charakteryzowane przez parametr $k_{t e}$, interakcje działania śrub z blachą czołową (end-plate) rygla. Z drugiej strony, ściskanie panelu środnika słupa odwzorowują sprężyny o charakterystyce $k_{c}$. W modelu tym nie rozpatruje się wpływu strefy ścinanej panelu środnika słupa, co w zasadzie ogranicza jego zastosowanie do węzłów z równymi momentami zginającymi przejmowanymi z rygli po lewej i prawej stronie słupa, a więc w praktyce 
jedynie do wewnętrznych węzłów badanej ramy. Oczywiście sprężyny rozciągane działają tu na ramionach $h_{t, i}$ wyznaczonych przez rozstaw kolejnych rzędów śrub, natomiast te ściskane na ramionach $h_{c, i}$, znacząco większych i determinowanych rozstawem osi pasów rygla.

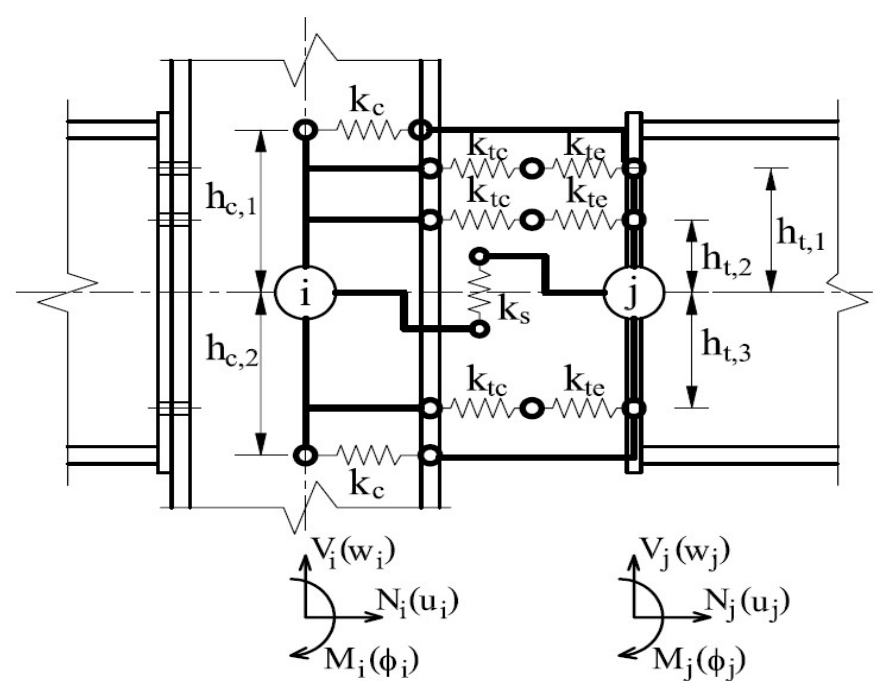

Rys. 5. Zastępczy model elementu węzłowego zaproponowany przez F. Blocka z zespołem - według $[14,15]$.

Fig. 5. An equivalent mechanically-based model of the nodal element proposed by $F$. Block with the team - according to $[14,15]$.

Szczegółowy schemat tak skonstruowanego modelu przedstawiono na rys. 5 przy oznaczeniu węzłów elementu, odpowiednio lewego i prawego, symbolami $i$ oraz $j$. Odległość między tymi węzłami uznawana jest za nieskonczenie małą toteż tak zdefiniowany element należy formalnie traktować jako jednowymiarowy. Element tego typu jest w wielu aspektach elementem prostszym w stosunku do tego, który został wcześniej przedstawiony na rys. 4., niemniej jednak jego podstawową zaletą jest możliwość stosunkowo łatwego dostosowania do analizy odniesionej do sytuacji pożaru, co postaramy się wykazać poniżej. Model elementu węzłowego prezentowany na rys. 5 może być udoskonalony poprzez dodanie kolejnych układów sprężyn, zwłaszcza takich, które pozwola na uwzględnienie oddziaływania ścinanych paneli środników rygla i słupa. Dwa z nich, proponowane do praktycznego zastosowania [16], pokazano na rys. 6. Zauważmy, że ścinanie tych składników węzła w obu przypadkach modelowane jest przez odpowiednie sprzężenie diagonalnie zorientowanych sprężyn. 
a)

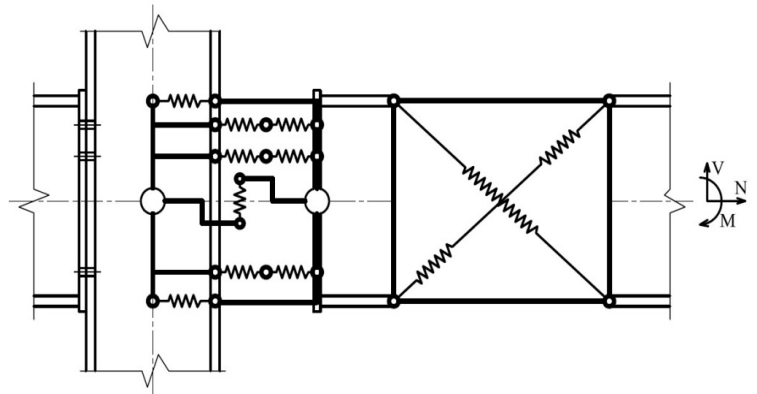

b)

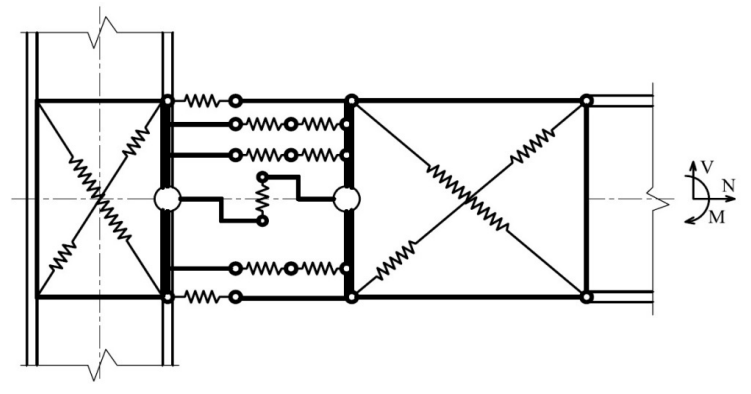

Rys. 6. Udoskonalone modele węzła z dodanymi elementami odzwierciedlającymi ścinanie paneli środników rygla (u góry - rys. 6a) oraz rygla i słupa (u dołu - rys. 6b) - według [16].

Fig. 6. The improved models of a steel end-plate beam-to-column joint with the added elements reflecting the impact of the shear force on the beam web (top - Fig. 6a) and on the both beam and column webs (bottom - Fig. 6b) - according to [16].

\section{Budowa macierzy sztywności siecznej elementu węzłowego odniesionej do sytuacji pożaru.}

Wybór zastosowanego modelu mechanicznego opisującego odpowiedź węzła na różnego typu wymuszenia determinuje strukturę charakteryzującej ten węzeł macierzy sztywności $\mathbf{K}_{\mathbf{c}}$. Jak pokazano we wprowadzeniu do niniejszych rozważań, w przypadku skojarzenia analizy statycznej badanej ramy $\mathrm{z}$ wyjątkową sytuacją projektową pożaru rozwiniętego macierz ta jest równoważna macierzy $\mathbf{K}_{c}^{*}$ budowanej w sposób iteracyjny. Szczegółowy algorytm specyfikacji poszczególnych wyrazów tej macierzy zostanie zaprezentowany w zastosowaniu do modelu będącego uproszczeniem układu sprężyn pokazanego na rys. 5. W modelu tym zdefiniowano dwie sprężyny translacyjne, rozmieszczone horyzontalnie $\mathrm{w}$ układzie równoległym i wyrażające odpowiedź węzła na zginanie momentem $M \mathrm{z}$ ewentualnym współudziałem siły osiowej $N$ oraz towarzyszącą tym sprężynom pojedynczą sprężynę pionową odzwierciedlającą reakcję węzła na działanie siły poprzecznej $V$. Schemat rozpatrywanego układu pokazano na rys. 7 . 

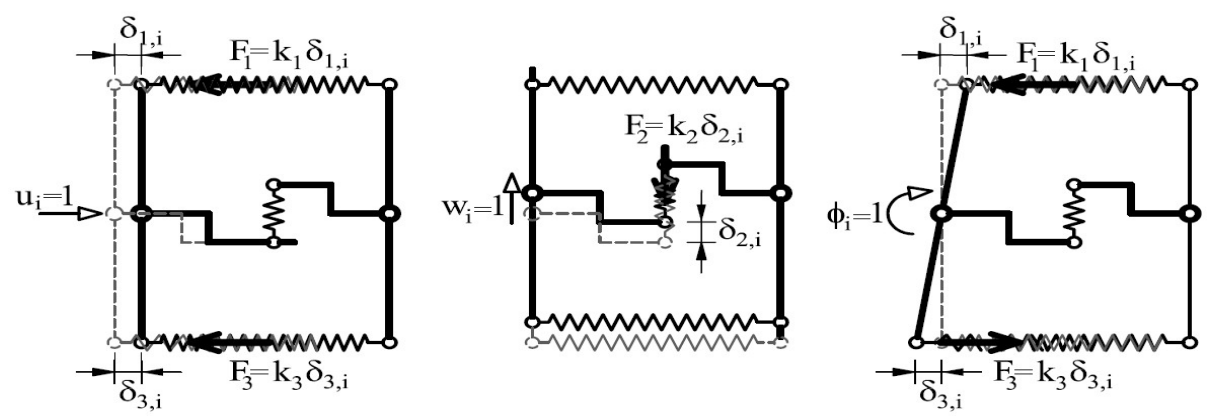

Rys. 7. Reakcja rozpatrywanego elementu węzłowego na poszczególne wymuszenia o wartości jednostkowej.

Fig. 7. The response of the considered nodal element on the individual excitations of the unit value.

Niech podatność sprężyn poziomych w danej temperaturze opisują znane a priori parametry $k_{1}-\mathrm{w}$ przypadku sprężyny górnej i $k_{3}-\mathrm{w}$ odniesieniu do sprężyny dolnej. Parametrem charakteryzującym sprężynę pionową jest w tym modelu czynnik $k_{2}$. Ramiona przyłożenia sił poziomych, skojarzone z odpowiednimi sprężynami, oznaczono odpowiednio przez $h_{1}$ i $h_{3}$, analogicznie jak na rys. 5. Zauważmy, że zarówno koniec elementu węzłowego opisany symbolem $i$ jak i drugi koniec oznaczony $\operatorname{przez} j$ znajdują się po tej samej (prawej) stronie osi słupa (węzeł jest jednostronny), stąd jednakowe zwroty przyłożonych do tych końców sił wewnętrznych. Rozpatruje się reakcję węzła na kolejne wymuszenia o wartości jednostkowej, to znaczy przy założeniu, że odpowiednio $u_{i}=1, w_{i}=1 \mathrm{i} \mathrm{w}$ końcu $\phi_{i}=1$, tak jak to zostało pokazane na rys. 7 . W szczególności dla końca $i$ otrzymano (siły $F_{i}$ są reakcjami generowanymi w poszczególnych sprężynach):

- przy wymuszeniu $u_{i}=1$ (rys. 7a):

$$
\begin{aligned}
& F_{1}=k_{1} u_{i} \text { oraz } F_{3}=k_{3} u_{i} \text { a zatem: } \\
& N_{i}=F_{1}+F_{3}=\left(k_{1}+k_{3}\right) u_{i} \text { co daje } K_{1,1}=k_{1}+k_{3} \\
& M_{i}=F_{1} h_{1}-F_{3} h_{3}=\left(k_{1} h_{1}-k_{3} h_{3}\right) u_{i} \text { co daje } K_{1,3}=k_{1} h_{1}-k_{3} h_{3}
\end{aligned}
$$

- przy wymuszeniu $w_{i}=1$ (rys. $7 \mathrm{~b}$ ):

$$
V_{i}=F_{2}=k_{2} w_{i} \quad \text { co daje } \quad K_{2,2}=k_{2}
$$

- przy wymuszeniu $\phi_{i}=1$ (rys. 7c):

$$
\begin{aligned}
& F_{1}=k_{1} h_{1} \phi_{i} \quad \text { oraz } \quad F_{3}=k_{3} h_{3} \phi_{i} \quad \text { a zatem: } \\
& N_{i}=F_{1}+F_{3}=\left(k_{1} h_{1}+k_{3} h_{3}\right) \phi_{i} \quad \text { co daje } \quad K_{3,1}=k_{1} h_{1}+k_{3} h_{3}
\end{aligned}
$$




$$
M_{i}=F_{1} h_{1}+F_{3} h_{3}=\left(k_{1} h_{1}^{2}+k_{3} h_{3}^{2}\right) \phi_{i} \text { co daje } K_{3,3}=k_{1} h_{1}^{2}+k_{3} h_{3}^{2}
$$

Powtórzenie analogicznej procedury $\mathrm{w}$ odniesieniu do końca $j$ daje następujące rezultaty:

- $K_{4,4}=k_{1}+k_{3}$

- $K_{4,6}=k_{1} h_{1}-k_{3} h_{3}$

- $K_{5,5}=k_{2}$

- $K_{6,4}=k_{1} h_{1}+k_{3} h_{3}$

- $K_{6,6}=k_{1} h_{1}^{2}+k_{3} h_{3}^{2}$ W tym:

Pozostałe elementy macierzy wynikają z globalnych równań równowagi.

- z sumy rzutów na oś poziomą, co oznacza że $N_{i}=-N_{j}$ :

$$
K_{1,4}=-\left(k_{1}+k_{3}\right) \quad \text { oraz } \quad K_{1,6}=-\left(k_{1} h_{1}-k_{3} h_{3}\right)
$$

- z sumy rzutów na oś pionową, co oznacza że $V_{i}=-V_{j}$ :

$$
K_{2,5}=-k_{2}
$$

- z warunku równowagi momentów zginających, co oznacza że $M_{i}=-M_{j}$ :

$$
K_{4,3}=-\left(k_{1} h_{1}-k_{3} h_{3}\right) \quad \text { oraz } \quad K_{6,3}=-\left(k_{1} h_{1}^{2}+k_{3} h_{3}^{2}\right)
$$

W rezultacie otrzymano macierz blokową z blokami rozmieszczonymi antysymetrycznie:

$$
\mathbf{K}_{c}^{*}=\left(\begin{array}{ccc|ccc}
\left(k_{1}+k_{3}\right) & 0 & \left(k_{1} h_{1}-k_{3} h_{3}\right) & -\left(k_{1}+k_{3}\right) & 0 & -\left(k_{1} h_{1}-k_{3} h_{3}\right) \\
0 & k_{2} & 0 & 0 & -k_{2} & 0 \\
\left(k_{1} h_{1}-k_{3} h_{3}\right) & 0 & \left(k_{1} h_{1}^{2}+k_{3} h_{3}^{2}\right) & -\left(k_{1} h_{1}-k_{3} h_{3}\right) & 0 & -\left(k_{1} h_{1}^{2}+k_{3} h_{3}^{2}\right) \\
\hline-\left(k_{1}+k_{3}\right) & 0 & -\left(k_{1} h_{1}-k_{3} h_{3}\right) & \left(k_{1}+k_{3}\right) & 0 & \left(k_{1} h_{1}-k_{3} h_{3}\right) \\
0 & -k_{2} & 0 & 0 & k_{2} & 0 \\
-\left(k_{1} h_{1}-k_{3} h_{3}\right) & 0 & -\left(k_{1} h_{1}^{2}+k_{3} h_{3}^{2}\right) & \left(k_{1} h_{1}-k_{3} h_{3}\right) & 0 & \left(k_{1} h_{1}^{2}+k_{3} h_{3}^{2}\right)
\end{array}\right)
$$

Dotychczasowa analiza dotyczyła uproszczonego elementu węzłowego $\mathrm{z}$ dwiema sprężynami zorientowanymi poziomo, w tym jednej rozciaganej (górnej) i jednej ściskanej (dolnej), oraz z jedną sprężyną pionową odwzorowującą reakcję na działanie siły poprzecznej. W praktyce, w typowych węzłach doczołowych projektuje się więcej niż jeden rząd śrub w strefie rozciąganej, a to wiąże się z koniecznością specyfikacji dodatkowych sprężyn rozciąganych. Możli- 
we jest również aby wskutek skrępowania swobody realizacji termicznie indukowanego wydłużenia elementów ramy zginaniu i ścinaniu węzła towarzyszyło jedynie ściskanie pochodzące od oddziaływania rygla. W takim przypadku element węzłowy powinien mieścić w sobie dwie poziome sprężyny ściskane, ulokowane $\mathrm{w}$ osiach obu pasów belki. Uwzględnienie wszystkich potencjalnie możliwych sytuacji obliczeniowych wymaga rozbudowy wyspecyfikowanej wcześniej macierzy sztywności $\mathbf{K}_{c}^{*}$. Jej ogólna postać została podana przez $F$. Blocka z zespołem w pracach [14, 15]. Jeżeli oznaczyć kolejno:

$$
\begin{aligned}
& K_{1,1}^{*}=\sum_{i=1}^{n} k_{t, i}^{*}+\sum_{i=1}^{2} k_{c, i}^{*} \\
& K_{1,5}^{*}=K_{5,1}^{*}=\sum_{i=1}^{n} h_{t, i} k_{t, i}^{*}+\sum_{i=1}^{2} h_{c, i} k_{c, i}^{*} \\
& K_{3,3}^{*}=k_{S}^{*} \\
& K_{5,5}^{*}=\sum_{i=1}^{n} h_{t, i}^{2} k_{t, i}^{*}+\sum_{i=1}^{2} h_{c, i}^{2} k_{c, i}^{*}
\end{aligned}
$$

przy czym dolne indeksy $t$ dotyczą $n$ sprężyn rozciąganych, $c$ - dwóch sprężyn ściskanych i $s$ - pojedynczej sprężyny ścinanej, zatem $n$ - jest liczbą rzędów śrub zidentyfikowanych w rozciąganej strefie węzła, to zachodzi:

$$
\mathbf{K}_{c}^{*}=\left(\begin{array}{cccccc|cccccc}
K_{1,1}^{*} & 0 & 0 & 0 & K_{1,5}^{*} & 0 & -K_{1,1}^{*} & 0 & 0 & 0 & -K_{1,5}^{*} & 0 \\
0 & \infty & 0 & 0 & 0 & 0 & 0 & -\infty & 0 & 0 & 0 & 0 \\
0 & 0 & K_{3,3}^{*} & 0 & 0 & 0 & 0 & 0 & -K_{3,3}^{*} & 0 & 0 & 0 \\
0 & 0 & 0 & \infty & 0 & 0 & 0 & 0 & 0 & -\infty & 0 & 0 \\
K_{5,1}^{*} & 0 & 0 & 0 & K_{5,5}^{*} & 0 & -K_{5,1}^{*} & 0 & 0 & 0 & -K_{5,5}^{*} & 0 \\
0 & 0 & 0 & 0 & 0 & \infty & 0 & 0 & 0 & 0 & 0 & -\infty \\
\hline-K_{1,1}^{*} & 0 & 0 & 0 & -K_{1,5}^{*} & 0 & K_{1,1}^{*} & 0 & 0 & 0 & K_{1,5}^{*} & 0 \\
0 & -\infty & 0 & 0 & 0 & 0 & 0 & \infty & 0 & 0 & 0 & 0 \\
0 & 0 & -K_{3,3}^{*} & 0 & 0 & 0 & 0 & 0 & K_{3,3}^{*} & 0 & 0 & 0 \\
0 & 0 & 0 & -\infty & 0 & 0 & 0 & 0 & 0 & \infty & 0 & 0 \\
-K_{5,1}^{*} & 0 & 0 & 0 & -K_{5,5}^{*} & 0 & K_{5,1}^{*} & 0 & 0 & 0 & K_{5,5}^{*} & 0 \\
0 & 0 & 0 & 0 & 0 & -\infty & 0 & 0 & 0 & 0 & 0 & \infty
\end{array}\right)
$$




\section{Uwagi końcowe}

Efektywne rozwiązanie równania (2), które determinuje podatność elementu wybranego do opisu zachowania się rozpatrywanego węzła w warunkach jego ekspozycji na temperaturę pożarową, staje się możliwe dzięki szczegółowej specyfikacji wyrazów macierzy sztywności siecznej $\mathbf{K}_{c}^{*}$. Jakkolwiek samo równanie daje różne wyniki w kolejnych krokach przyrostowych, przy postulowanej zbieżności uzyskiwanych oszacowań, to postać tej macierzy zależy jedynie od modelu odzwierciedlającego reakcję poszczególnych składników węzła na różnego typu wymuszenia (zginanie, ścinanie, ściskanie, rozciąganie). Należy podkreślić, że w ujęciu prezentowanym w niniejszych rozważaniach poszukiwaną podatność szacuje się przy założonej wartości temperatury węzła. Jest to zatem klasyczne zadanie izotermiczne. Zmiana tej temperatury wraz z rozwojem pożaru oznacza konieczność przeprowadzenia nowej analizy, odpowiadającej wygenerowanym na nowo wartościom sił wewnętrznych, a także zmienionym na skutek przyrostu tej temperatury cechom wytrzymałościowym stali. Z uwagi na silną i wieloźródłową nieliniowość przeprowadzanej analizy trzeba liczyć się z tym, że wynikowe oszacowanie podatności uzyskane przy założeniu konkretnych warunków panujących w węźle w danej, interesującej eksperta, chwili pożaru nie będzie jednoznacznie określone. Pomimo bowiem zadania niejako „na wyjściu” takiej samej miarodajnej temperatury węzła jego wyliczona podatność, kojarzona $\mathrm{z}$ tą temperatura, może być różna jeśli tylko różne były drogi dojścia do osiagnięcia tej temperatury (czyli tak zwana historia obciążenia).

Podstawą wiarygodnej specyfikacji poszczególnych elementów konstruowanej macierzy jest wcześniejsza identyfikacja miarodajnego modelu obliczeniowego charakteryzowanego przez założony a priori układ sprężyn odzwierciedlających odpowiedź myślowo wyizolowanych elementów węzła na jego ekspozycję pożarową. Dobrze, jeśli przyjęty zestaw pozwoli na uwzględnienie potencjalnej interakcji M-N i/lub M-V. Odnosząc się do warunków pożaru rozwiniętego trzeba podkreślić, że układ ten w swej zasadniczej strukturze nie ulega zmianie ze wzrostem temperatury modelowanych komponentów. Nie oznacza to jednak, że w takiej sytuacji stałe pozostaja również wyrazy macierzy $\mathbf{K}_{c}^{*}$. Zależą one bowiem wprost od parametrów $k_{i}$ charakteryzujących poszczególne sprężyny, parametry te zaś są funkcjami cech mechanicznych stali, z której wykonano elementy węzła, w szczególności jej granicy plastyczności i modułu sprężystości podłużnej, a te podlegają znaczącej redukcji jeśli tylko opisywany przez nie materiał zostanie odpowiednio ogrzany. 


\section{Literatura}

[1] Maślak M., Snela M.: Temperatura krytyczna ramy stalowej z malejącą w pożarze sztywnością węzłów, Zeszyty Naukowe Politechniki Rzeszowskiej, Nr 283, 2012, Seria „Budownictwo i Inżynieria Środowiska”, zeszyt 59 (3/12/II), s. 241-248.

[2] Maślak M., Litwin (Snela) M.: Podatność stalowego węzła belka - słup w temperaturze pożarowej, Inżynieria i Budownictwo, 8/2010, s. 441-445.

[3] PN-EN 1993-1-2: Eurokod 3: Projektowanie konstrukcji stalowych, Część 1-2: Reguły ogólne. Obliczanie konstrukcji z uwagi na warunki pożarowe.

[4] Maślak M., Litwin (Snela) M.: Zastępcza sztywność sieczna w szacowaniu odporności ogniowej nierównomiernie ogrzanych belek stalowych, Materiały LVI Konferencji Naukowej KILiW PAN i KN PZITB, Kielce - Krynica, 19-24.09.2010, s. 691-698.

[5] Simões da Silva L., Santiago A., Vila Real P.: A component model for the behavior of steel joints at elevated temperatures, Journal of Constructional Steel Research, 57, 2001, s. 1169-1195.

[6] Maślak M., Snela M.: Alternatywne metody identyfikacji charakterystyk moment obrót odniesionych do warunków pożaru, Czasopismo Inżynierii Lądowej, Środowiska i Architektury (Journal of Civil Engineering, Environment and Architecture), t. XXXI, z. 64 (4/14), październik - grudzień 2014, s. 135-145.

[7] Poggi C.: A finite element model for the analysis of flexible connected steel frames, International Journal for Numerical Methods in Engineering, 26, 1988, s. 2239 2254.

[8] Atamaz - Sibai W., Frey F.: New semi-rigid joint elements for non-linear analysis of flexibly connected frames, Journal of Constructional Steel Research, 25, 1993, s. $185-199$.

[9] Del Savio A.A., Nethercot D.A., Vellasco P.C.G.S., Andrade S.A.L., Martha L.F.: Generalised component-based model for beam-to-column connections including axial versus moment interactions, Journal of Constructional Steel Research, 65, 2009, s. $1876-1895$.

[10] PN-EN 1993-1-8: Eurokod 3: Projektowanie konstrukcji stalowych, Część 1-8: Projektowanie węzłów.

[11] Bródka J., Kozłowski A., Ligocki I, Łaguna J., Ślęczka L.: Projektowanie i obliczanie połączeń i węzłów konstrukcji stalowych, tom 1, Polskie Wydawnictwo Techniczne, Rzeszów, 2009.

[12] Li T.Q., Choo B.S., Nethercot D.A.: Connection element method for the analysis of semi-rigid frames, Journal of Constructional Steel Research, 32, 1995, s. 143-171.

[13] Bayo E., Cabrero J.M., Gil B.: An effective component-based method to model semi-rigid connections for the global analysis of steel and composite structures, Engineering Structures, 28, 2006, s. 97-108.

[14] Block F.M., Davison J.B., Burgess I.W., Plank R.J.: Principles of a componentbased connection element for the analysis of steel frames in fire, Engineering Structures, 49, 2013, s. 1059-1067.

[15] Block F.M., Burgess I.W., Davison J.B., Plank R.J.: The development of a component-based connection element for endplate connections in fire, Fire Safety Journal, 42, 2007, s. 498-506. 
[16] Burgess I: The problem of robustness in fire, Lecture presentation prepared for the COST TU 0904 Training School, June 6-9, 2013, Naples, Italy.

\section{THE RELIABLE STIFFNESS MATRIX IN THE FLEXIBILITY MODELLING FOR THE STEEL END-PLATE BEAM-TO-COLUMN JOINT WHEN EXPOSED TO A FIRE}

\section{S u m m a r y}

The computational procedure which allows to specify the components of the reliable stiffness matrix relating to the connection element modelling the flexibility of the considered steel end-plate beam-to-column joint when exposed to a fire is presented and widely discussed. The form of this matrix is determined by the conceptual mechanical model which has been accepted for the detailed analysis, forming the system of the springs imaginarily introduced to the structure and appropriately connected so as to reflect the reaction of the specific joint components on the excitations applied to them, with a unit value.

Keywords: stiffness matrix, flexible joint, nodal element, component method, fire.

Przestano do redakcji:25.06.2015

Przyjęto do druku:1.12.2015

DOI: $10.7862 / \mathrm{rb} .2015 .155$ 